\title{
Associated factors of electrical injuries and knowledge on their prevention and first aid management among Ceylon Electricity Board (CEB) field level technical workers in Colombo municipal area.
}

\author{
K A P Kuruppu Arachchi , P G K M Kumarawansha 1 , K A R L Kuruppu 1 , \\ Laboshan Kaliyugavarathan , Dulani Samaranayake \\ Faculty of Medicine, University of Colombo, Sri Lanka \\ 2 \\ Department of Community Medicine, Faculty of Medicine, University of Colombo, Sri Lanka
}

\begin{tabular}{ll}
\hline Article Information & $\begin{array}{l}\text { Abstract } \\
\text { Background }\end{array}$ \\
Total number of & Electrical injuries carry a high risk of morbidity and mortality. Electrical workers \\
Words 3062 & are at a constant risk of such injuries. Accurate knowledge on prevention and first \\
Tables 03 & aid and putting it into practice is important for preventing and reducing these \\
& injuries.
\end{tabular}
interest to declare

Keywords: Ceylon Electricity Board, Electrical injury, Knowledge, Prevention, First aid

\section{Objectives}

This study aimed to assess the associated factors of incidence of workplace electrical injuries and knowledge on prevention and first aid management among Ceylon Electricity Board (CEB) field level technical workers of the Colombo Municipal area.

Date of submission: 08.02.2017

Date of acceptance: 03.09.2017

DOI:

http://doi.org/10.4038/cjms.v54i2.4804

\section{Author responsible}

for correspondence:

Miss Prabhani Kuruppu Arachchi, Medical Student, Faculty of Medicine, PO Box 25, Kynsey Road, Colombo 8 prabhani92@gmail.com

https://orcid.org/0000-0003-2322-4042

\begin{abstract}
Methods
This is a descriptive cross-sectional study conducted among 120 field level technical workers selected through two-stage cluster sampling. An intervieweradministered questionnaire was employed to gather information. Data was analyzed using descriptive statistics and Chi-square test.

Results

The sample consisted of only males, with a mean age of 37.19 years $(\mathrm{SD}=11.08)$. Self-reported injury incidence among the workers was $6 \%$ per year and no significant association was seen between injury incidence and any of the sociodemographic or work-related characteristics. Majority had a good knowledge on prevention (75.8\%) and first aid management (81.7\%). Having a total number of 1 to 3 training sessions on prevention during the time of occupation showed a significant association with knowledge on prevention $(\mathrm{p}=0.006)$. Occupational grade showed a significant association with knowledge on first aid management $(\mathrm{p}=0.013)$.
\end{abstract}

\section{Conclusions}

The knowledge on prevention and first aid for electrical burn injuries was satisfactory. Occupational grade and the number of training programmes attended influenced their level of knowledge.

\section{Background}

Occupational injuries are defined as any personal injury, disease or death resulting from an occupational accident [1].Approximately 2.2 million people die, 270 million suffer serious non- fatal injuries and 160 million fall ill every year from occupational injuries all around the world. In Sri Lanka, about 4,000 accidents are being reported yearly and the number of working days lost is estimated to be around 600,000 workdays every year [2]. Electrical injuries are one type of such injuries. 


\section{Kuruppu Arachchi K A P et al}

Among 16000 Ceylon Electricity Board (CEB) workers, about $56.3 \%$ are technical workers who are skilled, semi-skilled or non-skilled. They are at constant risk of being exposed to electrical injuries, which are classified according to the number of days which a worker has been absent following an injury. In a minor injury, a worker reports to duty within 3 days and in a reportable injury it takes more than 3 days [3]. Seven fatal injuries (13.2\%), 36 reportable injuries $(67.9 \%)$ and 10 minor injuries $(18.9 \%)$ were among 53 such reported injuries in CEB during the year of 2014 [4].

In a study done in 2012, the prevalence of occupational injuries in CEB, Western Province North was 7.6 per 100 workers per 6 months and the annual estimated prevalence of such injuries was 15.2 per 100 workers. The pattern of injuries was different with $78.3 \%$ being due to minor injuries while $21.7 \%$ were reportable injuries [5].

Among factors associated with occupational injuries, the socioeconomic factors may be considered the most important. They exert a considerable influence on the injury frequency, especially if considered over a long period [6]. According to the study in 2012, occupational injuries were more likely to be in young $(<39$ years), married, unskilled, less experienced, less trained workers with frequent use of unsafe equipment [5].

International literature on the same topic suggest that the electrical injury incidents are associated with work inappropriately or inadvertently performed on energized equipment, failure to recognize all electrical sources, insufficient training and failure to use appropriate Personal Protective Equipment (PPE) [7].

In CEB workers at present, aspects practiced for preventing electrical injuries are proper use of PPE, maintaining safety distance from high voltage live conductors, proper supply interruption and earthing of lines at work and applying special safety methods [8].

Electric shock and electrical burns are serious injuries that should receive immediate medical attention. Contacting a first aid attendant plays a crucial role in such injury. Among Australian construction workers it has been observed that first aid training had a positive effect on the occupational safety and health behaviour by improving their desire to avoid occupational injuries [9].

Previous studies involving CEB workers have never involved the CEB field level technical staff in Colombo municipal area. In this study, we assessed the associated factors of workplace electrical injuries and knowledge on prevention and first aid management among CEB field level technical workers of the Colombo Municipal area.

\section{Methods}

This is a descriptive cross sectional study conducted in CEB depots situated in Colombo municipal area identified according to the official service area distribution of the CEB [3]. Our study population was 120 workers, selected from 450 CEB field level technical workers; skilled, semi-skilled and unskilled, working in 12 CEB depots within the stipulated area. Two stage cluster sampling method was used to select the workers. In the first stage, 8 out of 12 depots were selected randomly. From each depot, a cluster of 15 workers was selected using convenient sampling method.

All workers who were aged between 18 to 60 years, with more than one year work experience in the same work station were considered eligible for the study while office workers and those in supervising grade were excluded.

Ethical clearance was obtained from the Ethics Review Committee of Faculty of Medicine, Colombo. Approval was obtained from CEB authorities.

Primary data was obtained by an intervieweradministered questionnaire. The questionnaire contained sections to assess the incidence of injury, associated factors, knowledge on prevention and first aid. This was developed with the help of a group of experts (CEB supervisors). A pre-test was conducted before data collection to assess the understandability of the questions.

The participants were given a brief introduction about the study prior to obtaining informed written consent. The questions were asked in their mother tongue (Sinhalese and Tamil) and they were encouraged to clarify any doubts in the questions.

There were 12 and 10 closed-ended questions in the knowledge component of prevention and first aid sections respectively. A score of 1 was given to each knowledge-based question and a cut off value was decided to differentiate the subjects with good and poor knowledge with the advice of the CEB supervisors. Subjects with total score more than or equal to 8 in each component were considered having good level of knowledge.

The data collected, was analyzed using the SPSS software (version 20). Socio-demographic information was described using descriptive 
statistics. Factors associated with incidence of electrical injuries and knowledge on their prevention and first aid were tested using Chi-square test. P values less than 0.05 were considered statistically significant.

\section{Results}

The response rate was $100 \%$. All the participants were males and their mean age was 37.19 years

( $\mathrm{SD}=11.08)$. The socio-demographic and occupational characteristics of the sample are given in Table 01 .

Table 01: Socio- demographic and Occupational characteristics of the sample $(n=120)$

\begin{tabular}{|c|c|c|}
\hline & Frequency & Percent \\
\hline \multicolumn{3}{|l|}{ Age group } \\
\hline $21-30$ & 43 & 35.8 \\
\hline $31-40$ & 44 & 36.7 \\
\hline $41-50$ & 9 & 7.5 \\
\hline $51-60$ & 24 & 20.0 \\
\hline Total & 120 & 100.0 \\
\hline \multicolumn{3}{|l|}{ Race } \\
\hline Sinhalese & 117 & 97.5 \\
\hline Muslim & 2 & 1.7 \\
\hline Tamil & 1 & 0.8 \\
\hline Total & 120 & 100.0 \\
\hline \multicolumn{3}{|l|}{$\overline{\text { Marital status }}$} \\
\hline Married & 83 & 69.2 \\
\hline Unmarried & 36 & 30.0 \\
\hline Widowed & 1 & 0.8 \\
\hline Total & 120 & 100.0 \\
\hline \multicolumn{3}{|l|}{ Educational level } \\
\hline Grade $1-5$ & 1 & 0.8 \\
\hline Grade $6-10$ & 13 & 10.8 \\
\hline $\mathrm{O} / \mathrm{L}$ & 49 & 40.8 \\
\hline $\mathrm{A} / \mathrm{L}$ & 39 & 32.5 \\
\hline$>\mathrm{A} / \mathrm{L}$ & 18 & 15.0 \\
\hline Total & 120 & 100.0 \\
\hline \multicolumn{3}{|l|}{$\begin{array}{l}\text { Average monthly } \\
\text { income }\end{array}$} \\
\hline Rs. $<20000$ & 5 & 4.2 \\
\hline Rs. $20000-30000$ & 38 & 31.7 \\
\hline Rs. $30000-40000$ & 31 & 25.8 \\
\hline Rs. $>40000$ & 46 & 38.3 \\
\hline Total & 120 & 100.0 \\
\hline \multicolumn{3}{|l|}{$\begin{array}{l}\text { Frequency of } \\
\text { alcohol use }\end{array}$} \\
\hline Never & 59 & 49.2 \\
\hline Daily & 2 & 1.7 \\
\hline Weekly & 21 & 17.5 \\
\hline Occasionally & 38 & 31.6 \\
\hline Total & 120 & 100.0 \\
\hline
\end{tabular}

\begin{tabular}{|c|c|c|}
\hline \multicolumn{3}{|l|}{ Smoking } \\
\hline Yes & 32 & 26.7 \\
\hline No & 88 & 73.3 \\
\hline Total & 120 & 100.0 \\
\hline \multicolumn{3}{|c|}{$\begin{array}{l}\text { Occupational } \\
\text { grade }\end{array}$} \\
\hline Skilled & 41 & 34.2 \\
\hline Semi-skilled & 28 & 23.3 \\
\hline Unskilled & 51 & 42.5 \\
\hline Total & 120 & 100.0 \\
\hline \multicolumn{3}{|c|}{$\begin{array}{l}\text { Work experience } \\
\text { in current job }\end{array}$} \\
\hline$<5$ years & 43 & 35.8 \\
\hline$>5$ years & 77 & 64.2 \\
\hline Total & 120 & 100.0 \\
\hline \multicolumn{3}{|c|}{$\begin{array}{l}\text { Work experience } \\
\text { in current } \\
\text { location }\end{array}$} \\
\hline$<5$ Years & 80 & 66.7 \\
\hline$>5$ Years & 40 & 33.3 \\
\hline Total & 120 & 100.0 \\
\hline \multicolumn{3}{|c|}{$\begin{array}{l}\text { Working hours } \\
\text { per day }\end{array}$} \\
\hline$<8$ hours & 20 & 16.7 \\
\hline$>8$ hours & 100 & 83.3 \\
\hline Total & 120 & 100.0 \\
\hline \multicolumn{3}{|c|}{$\begin{array}{l}\text { Working days per } \\
\text { week }\end{array}$} \\
\hline$<5$ days & 33 & 27.5 \\
\hline$>5$ days & 87 & 72.5 \\
\hline Total & 120 & 100.0 \\
\hline
\end{tabular}

From October 2014 to October 2015, 6 out of the 120 workers $(5 \%)$ have faced electrical injuries. One worker had 2 injuries and rest had only 1 injury. All injuries were minor, low voltage electrical injuries. Based on this, the calculated incidence of electrical injuries in this cohort of workers is 5.83 per 100 workers per year.

Table 02 shows the factors associated with incidence of electrical injuries. However, we were not able to find any significant association between sociodemographic factors and the incidence of electrical injuries. Work related characteristics such as occupational grade $(\mathrm{p}=1.0)$, work experience in current job $(\mathrm{p}=1.0)$, work experience in current work location $(\mathrm{p}=0.6)$, working hours per day $(\mathrm{p}=0.6)$, working days per week $(\mathrm{p}=0.08)$, number of training sessions on prevention of electrical injuries $(\mathrm{p}=0.8)$, knowledge on prevention $(\mathrm{p}=1.0)$ and alcohol consumption $(p=0.6)$ of the workers were also not significantly associated with the incidence of electrical injuries. 
Table 02: Factors associated with incidence of electrical injuries $(n=120)$

\begin{tabular}{|c|c|c|c|c|c|}
\hline & \multicolumn{2}{|c|}{$\begin{array}{c}\text { Electrical } \\
\text { Injuries }\end{array}$} & \multicolumn{2}{|c|}{$\begin{array}{c}\text { No Electrical } \\
\text { Injuries }\end{array}$} & \multirow[t]{2}{*}{$p$ value } \\
\hline & Frequency & Percent & Frequency & Percent & \\
\hline \multicolumn{6}{|l|}{ Age } \\
\hline$<40$ years & 4 & 4.6 & 83 & 95.4 & 1.00 \\
\hline$>40$ years & 2 & 6.1 & 31 & 93.9 & \\
\hline \multicolumn{6}{|l|}{ Marital status } \\
\hline Married & 2 & 2.4 & 81 & 97.6 & 0.14 \\
\hline Unmarried/Widowed & 4 & 10.8 & 33 & 89.2 & \\
\hline \multicolumn{6}{|l|}{ Educational level } \\
\hline$\leq \mathrm{O} / \mathrm{L}$ & 4 & 6.3 & 59 & 93.7 & 0.77 \\
\hline$>\mathrm{O} / \mathrm{L}$ & 2 & 3.5 & 55 & 96.5 & \\
\hline \multicolumn{6}{|l|}{ Alcohol use } \\
\hline Yes & 2 & 3.3 & 59 & 96.7 & 0.65 \\
\hline No & 4 & 6.8 & 55 & 93.2 & \\
\hline \multicolumn{6}{|l|}{ Smoking } \\
\hline Yes & 1 & 3.1 & 31 & 96.9 & 0.93 \\
\hline No & 5 & 5.7 & 83 & 94.3 & \\
\hline \multicolumn{6}{|l|}{ Occupational grade } \\
\hline Skilled & 2 & 4.9 & 39 & 95.1 & 1.00 \\
\hline Semi-skilled/Unskilled & 4 & 5.1 & 75 & 94.9 & \\
\hline \multicolumn{6}{|l|}{ Work experience in current job } \\
\hline$\leq 5$ years & 2 & 4.7 & 41 & 95.3 & 1.00 \\
\hline$>5$ years & 4 & 5.2 & 73 & 94.8 & \\
\hline \multicolumn{6}{|l|}{ Working experience in current location } \\
\hline$\leq 5$ years & 5 & 6.3 & 75 & 93.7 & 0.66 \\
\hline$>5$ years & 1 & 2.5 & 39 & 97.5 & \\
\hline \multicolumn{6}{|l|}{ Working hours per day } \\
\hline$\leq 8$ hours & 2 & 10.0 & 18 & 90.0 & 0.57 \\
\hline$>8$ hours & 4 & 4.0 & 96 & 96.0 & \\
\hline \multicolumn{6}{|l|}{ Working days per week } \\
\hline$\leq 5$ days & 4 & 12.1 & 29 & 87.9 & 0.08 \\
\hline$>5$ days & 2 & 2.3 & 85 & 97.7 & \\
\hline \multicolumn{6}{|l|}{ No of training sessions on prevention } \\
\hline$\leq 3$ times & 5 & 5.9 & 79 & 94.1 & 0.83 \\
\hline$>3$ times & 1 & 2.9 & 33 & 97.1 & \\
\hline \multicolumn{6}{|l|}{ Knowledge on prevention } \\
\hline Good & 5 & 5.5 & 86 & 94.5 & 1.00 \\
\hline Poor & 1 & 5.3 & 28 & 94.7 & \\
\hline \multicolumn{2}{|l|}{$\begin{array}{l}\text { Hundred and eighteen (98\%) workers had } \\
\text { participated in workshops on prevention of electrical } \\
\text { injuries and } 84(71 \%) \text { of them had participated in } \\
\text { training sessions up to 1-3 times. Eighty }(66.7 \%) \\
\text { have had the last training within past three years. }\end{array}$} & \multicolumn{4}{|c|}{$\begin{array}{l}\text { (64\%) have had the last training session within last } \\
\text { three years. When considering the knowledge on } \\
\text { prevention and first aid, } 75.8 \% \text { and } 81.7 \% \text { had a } \\
\text { good level of knowledge on prevention and first aid } \\
\text { management of electrical injuries respectively. }\end{array}$} \\
\hline \multicolumn{2}{|l|}{$\begin{array}{l}\text { Hundred and seventeen }(97.5 \%) \text { workers had } \\
\text { participated in workshops on first aid management of } \\
\text { electrical injuries and } 87(74.4 \%) \text { of them had } \\
\text { participated in 1-3 training sessions. Seventy seven }\end{array}$} & \multicolumn{4}{|c|}{$\begin{array}{l}\text { Table } 03 \text { shows factors associated with knowledge } \\
\text { on prevention of electrical injuries and factors } \\
\text { associated with knowledge on first aid management } \\
\text { of electrical injuries. In the study, we found that }\end{array}$} \\
\hline
\end{tabular}


having 1 to 3 training sessions on prevention and knowledge on prevention has a significant association $(p=0.006)$. We were not able to find any significant association between factors such as educational level $(\mathrm{p}=0.3)$, young age of $<40$ years $(\mathrm{p}=0.1)$, alcohol consumption $(\mathrm{p}=0.9)$, occupational grade $(\mathrm{p}=0.2)$ and work experience $(\mathrm{p}=1.0)$ of the workers and their knowledge on prevention.
Occupational grade showed a significant association with their knowledge on first aid management $(\mathrm{p}=0.01)$ but none between factors such as age $(\mathrm{p}=0.07)$, educational level $(\mathrm{p}=1.0)$, alcohol consumption $(\mathrm{p}=1.0)$, number of training sessions of first aid $(\mathrm{p}=0.6)$ and work experience $(\mathrm{p}=1.0)$.

Table 03: Factors associated with knowledge on prevention of electrical injuries and with knowledge on first aid management of electrical injuries

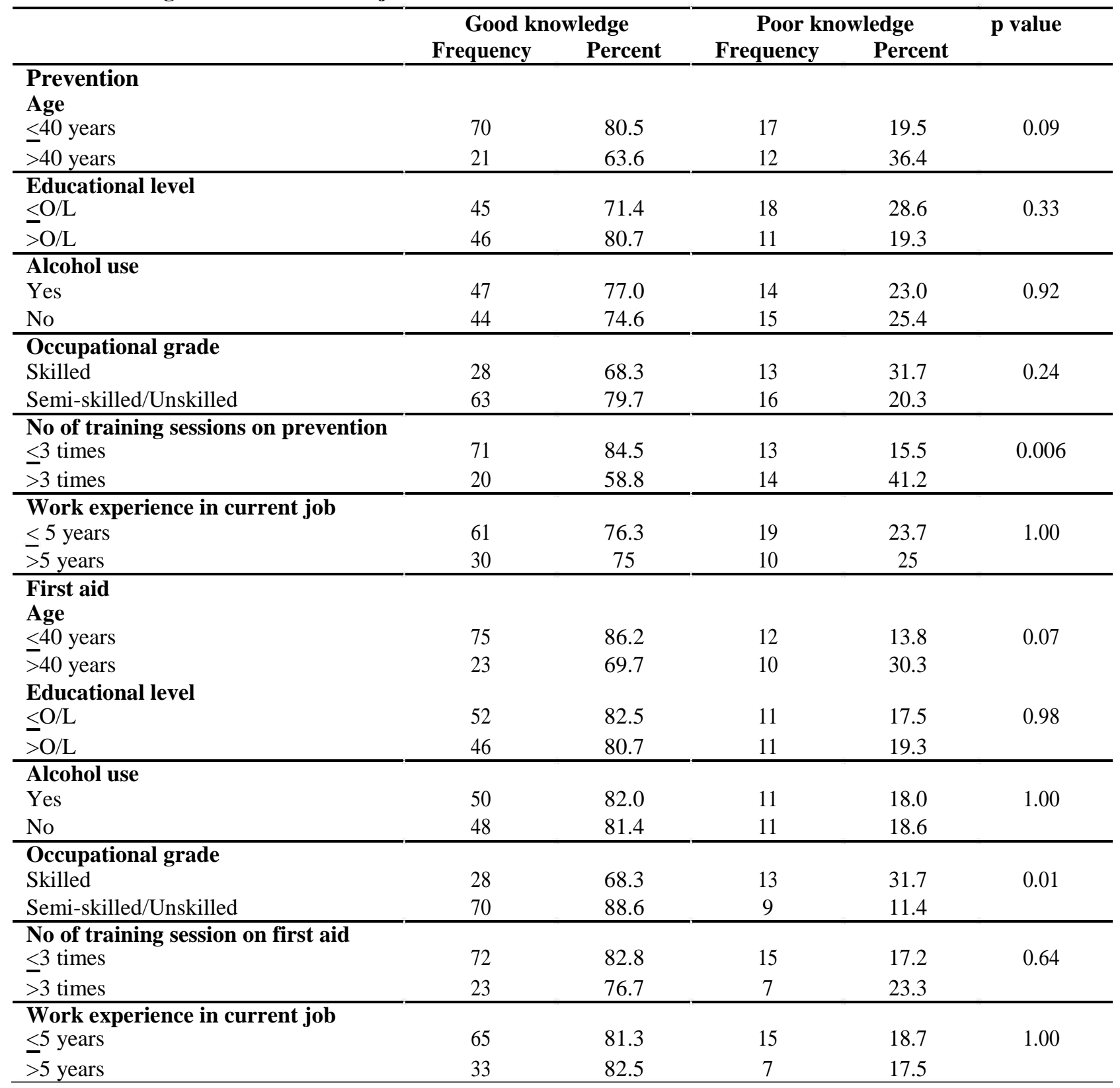

\section{Discussion}

Electrical injuries are one type of dangerous occupational injuries. From 2003-2007, Electrical Safety Foundation International have found that 1213 workers have died on the job due to contact with electrical current. Out of these, $43 \%$ were due to contact with overhead power lines, $28 \%$ due to contact with wiring transformers or other electrical components and $18 \%$ due to contact with electrical current from machine, tools and appliances or light fixtures [10].

According to Trends in electrical injury in the US 1992-2002 article the electricians and their apprentices sustained most electrical fatalities, and electric power installers and repairers ranked third. 
They are high risk groups for electrical injuries. They report that 46598 workers were non fatally injured by electricity: $36 \%$ due to contact with electric current of machine, tool, appliance, or light fixture and $34 \%$ due to contact with wiring, transformers, or other electrical components [11].

Although there are many studies focused on occupational injuries among worker categories like tea plantation and rubber plantation workers in Sri Lanka [12,13] there are only few focused specifically on electrical workers [5]. The present study addressed the associated factors of workplace electrical injuries among CEB field level technical workers of the Colombo municipal area and their knowledge on prevention and first aid management at the time of an electrical injury.

Seven fatal injuries (13.2\%), 36 reportable injuries $(67.9 \%)$ and 10 minor injuries (18.9\%) among the 53 reported occupational injuries in the CEB occupational settings in Sri Lanka during the year of 2014[4]. In the study among labourers of CEB in Western Province North in 2012, 18 minor (78.3\%) and $5(21.7 \%)$ reportable injuries within 6 months reported a prevalence of occupational injuries as 7.6 per 100 workers per 6 months and annual estimated prevalence of 15.2 per 100 workers [5]. In comparison, the prevalence in our study was low and all injuries were minor and low voltage injuries. This difference could be due to the small sample size and the retrospective nature of our study. Our study which used a recall period of one year may also contribute to some minor injuries not being recalled.

In comparison to the 2012 study, where a significant association was reported between younger age (2039 years) and marital status with the prevalence of electrical injuries $(\mathrm{p}=0.03$ and $\mathrm{p}=0.004$ respectively) [5], our study did not find any association between age of the worker or their marital status and the occurrence of electrical injuries. This difference may be due to small sample size of the present study. Both present study and previous study in 2012 showed higher injury incidences in unskilled occupational grade but neither findings were statistically significant [5].

In a study conducted among Australian construction workers, it was observed that first aid training had a positive effect on the occupational safety and the healthy behavior of workers by improving their desire to avoid occupational injuries [9]. However, in our study there was no significant association between the knowledge and prevention of electrical injuries and the incidence of electrical injuries.

Percentage with good level of knowledge on prevention and first aid management of electrical injuries were at $75.8 \%$ and $81.7 \%$ respectively. This was a satisfactory situation and the regular training programmes conducted for CEB employees may have contributed. Level of knowledge on both prevention and first-aid seemed to be better in the younger group $(<40$ years $)$, but this was not statistically significant.

Number of training programmes showed an inverse association with knowledge on prevention. This was an unexpected finding. However, consideration of the cumulative number of training programmes rather than how recently further training occurred as well as categorization of level of knowledge as 'good' and 'poor' based on recommendations of the CEB supervisors could have contributed to an error.

Occupational grade of the workers and their knowledge on first aid management showed a significant association $(\mathrm{p}=0.01)$ in the current study. Higher working experience and number of training sessions associated with higher occupational grade could have accounted for this finding although they were not significant as individual factors.

In this study, the Colombo municipal area was used to include a larger number of employees in an urban setting at a higher risk of electrical injuries. However the findings may not be applicable to all the CEB field level workers in Sri Lanka.

Since this was an interviewer-administered questionnaire, the workers were sometimes reluctant to give the actual data. Self-reporting bias could not be excluded. Since this analysis relied on self-report information, some participants may have underreported injuries because they had not reported about that particular injury to the authorities at the time of the injury or because they had forgotten about minor injuries. Assessing the association between training sessions done before the October 2014 with injuries from October 2014 to October 2015 would have been better than recalling after a period of one year.

\section{Conclusions}

Self-reported injury incidence among the workers was about $6 \%$ per year and there was no significant association between injury incidence and any of the socio-demographic or work-related characteristics. Knowledge on prevention and first-aid of electrical injuries was satisfactory in a majority. Only the number of training programmes with the knowledge on prevention and occupational grade with the knowledge on first aid management showed significant associations. 


\section{Acknowledgement}

We would like to show our gratitude to Community stream, Faculty of medicine, Colombo for their guidance and to the administrative staff and officers in charge of the depots of Ceylon Electricity Board in Colombo municipal area for their support.

\section{References}

1. Glossary of statistical terms [Internet]. Organization for Economic Co-operation and Development; [cited 2017September]. Available from: https://stats.oecd.org/glossary/detail.asp?ID=3565

2. Safety and health at work in Sri Lanka and the Maldives [Internet]. International Labour Organization; [cited 2017September]. Available from: http://www.ilo.org/colombo/areasofwork/safety-andhealth-at-work/lang--en/index.htm

3. Ceylon Electricity Board. Ceylon Electricity Board Annual Report 2012. Sri Lanka. CEB. 2012.

4. CEB accident report summary- 2008-2014. Ceylon Electricity Board Technical Training Centre, Piliyandala. 2015.

5. Mambulage RU. The prevalence and pattern of occupational injuries, its associated factors and health and safety practices among labourers of Ceylon Electricity Board, Western Province North. Postgraduate institute of Medicine, University of Colombo. 2012.

6. Fabiano B, Currò F, Pastorino R. Occupational injuries in Italy: risk factors and long term trend (1951-98). Occupational and Environmental Medicine2001;58:330-338; [cited 2017September]. Available from: http://oem.bmj.com/content/58/5/330
7. Campbell RB, Dini DA. Occupational Injuries from Electrical Shock and Arc Flash Events [Internet]. USA: Fire Protection Research Foundation. 2015; [cited 2017September]. Available from: http://www.nfpa.org/news-andresearch/fire-statistics-and-reports/researchreports/electrical-safety/occupational-injuriesfrom-electrical-shock-and-arc-flash-events

8. Ceylon Electricity Board. Safety hand book. Sri Lanka: Ceylon Electricity Board; 2009.

9. Lingard $\mathrm{H}$. The effect of first aid training on Australian construction workers' occupational health and safety motivation and risk control behaviour [abstract].J Safety Res. Summer 2002; 33:P209-230; [cited 2017September]. Available from:

https://www.ncbi.nlm.nih.gov/pubmed/12216447

10. Brenner B, Cawley JC. Occupational Electrical Injury and Fatality Trends: 1992-2007. EHS Today. 2009; [cited 2017December]. Available from: http://ehstoday.com/construction/news/occupational electrical-injury-3991;

11. Cawley JC. Homce GT. Trends in Electrical Injury, 1992-2002. Petroleum and Chemical Industry Conference. 2006 (PCIC '06'): IEEE Industry Applications Society, 53rd Annual. 1 - 14. 10.1109/PCICON.2006.359722; [cited 2017December]. Available from: https://www.researchgate.net/publication/224703507_Trends in Electrical Injury 1992-2002

12. Udayasiri AAT. Selected occupation related health problems in Tea plantation workers in Kegalle District. Postgraduate institute of Medicine, University of Colombo. 2002.

13. Jayathilake HKTM. Occupation related health problems among rubber plantation workers in Kalutara District. Postgraduate institute of Medicine, University of Colombo. 2010. 